\title{
Rootstock-scion interaction: 6. Phenology, chilling and heat requirements of Cabernet Sauvignon grapevine
}

\begin{abstract}
Alberto Miele ${ }^{1}$
Abstract - The grapevine phenology is dependent on several factors, such as genetics, soil characteristics, climate conditions, pests and diseases and vineyard cultural practices. Among these, grafting may have an effect on the scion behavior due to the influence of the rootstock. Therefore, an experiment was carried out for two years to determine the effect of rootstocks on Cabernet Sauvignon (CS) grapevine phenology, chilling and heat requirements. Treatments consisted of vines grafted on the rootstocks Rupestris du Lot, 101-14 Mgt, 3309 C, 420A Mgt, 5BB K, 161-49 C, SO4, Solferino, 1103 P, 99 R, 110 R, Gravesac, Fercal, Dogridge and Isabel. Budbreak and flowering of the vines, veraison and maturity of the grapes were the phenological stages evaluated, determining the dates of each stage and the number of days between them. The chilling hours (Tbase $=10^{\circ} \mathrm{C}$ ) for budbreak and the heat summation required to ripen the grapes were also determined. The results showed that the dates of each phenological stage varied according to the year and the rootstock. The average of two years showed that CS/3309 C, CS/161-49 C and CS/101-14 Mgt sprouted earlier and CS/Dogridge later. Grape maturity was earlier on seven CS/rootstocks, where CS/101-14 Mgt and CS/Rupestris du Lot ripened first and CS/Isabel, CS/5BB K and CS/SO4 later. The average intervals between the stages of CS/rootstocks were (in days), $46.8 \pm 3.0$ (budbreak-flowering), $64.3 \pm 2.1$ (floweringveraison), $54.6 \pm 6.1$ (veraison-maturity) and 165.7 \pm 7.4 (budbreak-maturity). In 1998, 615.9 \pm 8.0 chill hours were needed to achieve $50 \%$ budbreak and in $1999,870.6 \pm 6.5$ chill hours, where CS/Dogridge required the highest chilling to break dormancy. In order to ripen the grapes, the heat requirement from budbreak to maturity was $1573.4 \pm 43.0{ }^{\circ} \mathrm{C}$ in $1998 / 1999$ and $1599.4 \pm 25.5^{\circ} \mathrm{C}$ in $1999 / 2000$, and the juice total soluble solids values were 19.1 and $18.1^{\circ}$ Brix, respectively. Although the heat summation of the second cycle was $1.65 \%$ higher, the total soluble solids were lower due to the rainfall that was much higher during its grape ripening period.
\end{abstract}

Index terms: Vitis vinifera, viticulture, grape, phenological stages.

\section{Interação entre porta-enxerto e copa: 6. Fenologia e requerimentos de frio e calor da videira Cabernet Sauvignon}

\begin{abstract}
Corresponding author: alberto.miele@embrapa.br

Received: February 06,2019 Accepted: July 24, 2019
\end{abstract}

Copyright: All the contents of this journal, except where otherwise noted, is licensed under a Creative Commons Attribution License.

\section{(cc) $\mathbf{E Y}$}

Resumo - A fenologia da videira depende de vários fatores, como genética, características do solo, condições climáticas, pragas e doenças, e práticas culturais do vinhedo. Dentre estas, o porta-enxerto pode ter influência no comportamento da copa. Devido a isso, este experimento foi conduzido por dois anos para determinar o efeito do porta-enxerto na fenologia e nas necessidades de frio e calor da videira. Os tratamentos consistiram na videira Cabernet Sauvignon (CS) enxertada nos porta-enxertos Rupestris du Lot, 101-14 Mgt, C 3309, 420A Mgt, K 5BB, C 161-49, SO4, Solferino, P 1103, R 99, R 110, Gravesac, Fercal, Dogridge e Isabel. Avaliaram-se a quebra de dormência e a floração da videira, e o início de maturação e a maturidade da uva, determinando as datas de cada fase e o número de dias entre elas. Foram determinados, também, o número de horas de frio ( $\mathrm{Tbase}=10^{\circ} \mathrm{C}$ ) necessário para a quebra de dormência e a soma térmica para amadurecer a uva. Os resultados mostraram que as datas das fases fenológicas variaram de acordo com o ano e o portaenxerto. Na média dos dois anos, CS/C 3309, CS/C 161-49 e CS/101-14 Mgt brotaram mais cedo, enquanto CS/Dogridge, mais tarde. A uva das combinações CS/101-14 Mgt e CS/Rupestris du Lot amadureceu mais cedo, e de CS/Isabel, CS/K 5BB e CS/SO4, mais tarde. As médias entre as fases fenológicas de $\mathrm{CS} /$ porta-enxertos foram (em dias), 46,8 $\pm 3,0$ (quebra de dormência-floração), 64,3 $\pm 2,1$ (floração-início da

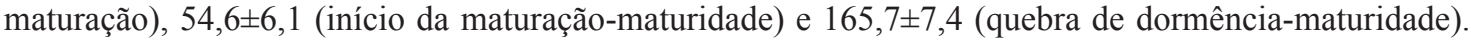
Em 1998, 50\% das gemas brotaram com $615,9 \pm 8,0$ horas de frio, e em 1999, com 870,6 $\pm 6,5$, sendo que $\mathrm{CS} /$ Dogridge foi o que necessitou de mais frio. Da quebra de dormência à maturidade da uva, a soma térmica foi $1.573,4 \pm 43,0^{\circ} \mathrm{C}$ em $1998 / 1999$ e $1.599,4 \pm 25,5^{\circ} \mathrm{C}$ em $1999 / 2000$, e os sólidos solúveis totais da uva foram 19,1 e 18,1 ${ }^{\circ}$ Brix, respectivamente. Apesar de a soma térmica ter sido $1,65 \%$ mais elevada no segundo ciclo, os sólidos solúveis totais apresentaram teor menor devido ao volume de chuva ter sido maior durante o período de maturação do fruto.

Termos para indexação: Vitis vinifera, viticultura, uva, fases fenológicas. 


\section{Introduction}

Climate changes are a human concern because they may affect agriculture in different ways (IPCC, 2015). In this sense, grapevines may also be affected, since they are cultivated in a wide range of latitudes, which vary mainly from $20^{\circ}-50^{\circ} \mathrm{N}$ to $20^{\circ}-40^{\circ} \mathrm{S}$. Indeed, they may affect the vine yield (ACOSTA et al., 2012), fruit composition and wine quality (JONES; DAVIS, 2000). They may also modify the limits of winegrowing regions, such as those of Denomination of Origin (MORIONDO et al., 2013). With regard to grapevine phenology, they may change the dates of budbreak, flowering, veraison, maturity and leaf fall (VINK et al., 2012; CABRÉ et al., 2016; HALL et al., 2016; RUML et al., 2016).

The study of vine phenology stages is important for the grape grower, since it allows planning the cultural practices of the vineyard, such as the works related to pruning, control of pests and diseases and time of grape harvest (MANDELLI et al., 2003). In addition, the relationships between phenology stages and climatic parameters may be used to develop prediction models (URHAUSEN et al., 2011) which may be useful for the planning of long-term impact assessment of climate change (FRAGA et al., 2016) and are important tools for a breeding program (DUCHÊNE et al., 2012).

In temperate climates, grapevine leaves fall in autumn, which leads to the plant dormancy period in winter. The length and intensity of low temperatures depend on the location and year, and are important factors in assuring a high percentage of budbreak in a short time, which allows for a desirable standard of the vineyard. The timing of chilling is also important for grape growers. In fact, early chilling followed by premature warming may injure vine buds, delay budbreak or lead to non-uniform budbreak (MATHIASON et al., 2009). In this case, budbreak promoters are used (MIELE, 1991).

The chilling requirement was then developed to determine the dates of budbreak and the number of burst buds in the vineyard, which is described in chill units ( 1 chill unit $=1$ chill hour), which means the total number of hours below $10{ }^{\circ} \mathrm{C}$ to which a plant is exposed during the rest period for breaking dormancy (WINKLER et al., 1974). However, the base temperature may differ according to the cultivar (ZAPATA et al., 2015) and to where - such as latitude - the vines are grown.

When the rest period is over, the buds start to sprout using the energy accumulated mainly in the permanent parts of the vine - arms, trunk and roots - in the form of starch (ZUFFEREY et al., 2012). However, later when the photosynthetic apparatus is functional, growth and development occur due to photosynthesis, which depends on the energy coming from solar radiation. The growing degree day (GDD) is used in this case (WINKLER et al., 1974) to determine the thermal needs of a plant to ripen grapes from vine budbreak. Indeed, there is a positive correlation between the increase of air temperature and vine phenology (HALL et al., 2016). The accumulated GDD may vary in response to the cultivar, region, climatic conditions and cultural practices performed in the vineyard.

Among the cultural practices which have an effect on the grapevine phenology stages, the pruning time is mentioned (MURAKAMI et al., 2002; TECCHIO et al., 2013; GATTI et al., 2016; PETRIE et al., 2017), winter and summer pruning (ANZANELLO et al., 2012), canopy management (TROUGHT et al., 2011), irrigation (VERDUGO-VÁSQUEZ et al., 2016) and growth in greenhouse (SCHIEDECK et al., 1997). The effect of rootstock on the vine phenology is reported for the heat requirement of Vitis labrusca (SATO et al., 2008; TECCHIO et al., 2011) and Vitis vinifera varieties (ALLEBRANDT et al., 2015), including table grape (BENJAMIN et al., 2018).

Thus, this study aimed to determine the phenological stages of Cabernet Sauvignon, the chilling requirement for break bud dormancy and the heat requirement from vine budbreak to grape maturity of this variety grafted on 15 rootstocks.

\section{Material and Methods}

The experiment was carried out for two consecutive years - 1998/1999 and 1999/2000 - in the Serra Gaúcha viticultural region, Brazil, in a Cambissolo soil, whose coordinates were $29^{\circ} 09^{\prime} 44^{\prime \prime} \mathrm{S}$ and $51^{\circ} 31^{\prime} 50^{\prime \prime} \mathrm{W}, 640 \mathrm{~m}$ high. The climatic data from May 1998 to March 1999 and May 1999 to March 2000, that is, the average for maximum, minimum and mean temperatures, were from Embrapa Uva e Vinho database and the climatological normals (1981-2010), such as, maximum, minimum and mean were from INMET(2018) (Figure 1).

Treatments consisted of Cabernet Sauvignon (Vitis vinifera $\mathrm{L}$.) grapevine grafted on the rootstocks Rupestris du Lot, 101-14 Millardet e de Grasset, 3309 Couderc, 420A Millardet e de Grasset, 5BB Kober, 161-49 Couderc, SO4, Solferino (local name of an unknown rootstock), 1103 Paulsen, 99 Richter, 110 Richter, Gravesac, Fercal, Dogridge and Isabel. The origin of the genetic material was previously described (MIELE; RIZZO, 2017).

The vineyard consisted of 450 plants, 30 of each Cabernet Sauvignon/rootstock (CS/rootstock), distributed in three blocks. Data related to vineyard management were previously shown (MIELE; RIZZON, 2017). Pruning was performed on September $3^{\text {tr }}, 1998$ and September $2^{\text {nd }}, 1999$, in the vine's dormant period. The dates of vine budbreak and flowering, and grape veraison and maturity were assessed. The budbreak dates were recorded when $50 \%$ of the buds had been burst, which was done by counting daily the total number of buds and the number 
of burst buds, when the rosette leaf tips were green (LORENZ et al., 1995). The percentage of burst buds was determined in spurs and canes at the end of October, by counting the total number of buds and those already burst. The flowering dates were determined when $50 \%$ of the calyptras had already fallen, by counting the number of total inflorescences and those with $\geq 50 \%$ of open flowers.
The veraison, when $50 \%$ of the grape skins reached 'red' color and maturity when the total soluble solids (TSS) $\left({ }^{\circ}\right.$ Brix) of the grape juices no longer increased. The TSS was measured daily at the end of grape ripening by means of a hand refractometer; titratable acidity (TA) $\left(\mathrm{meq} \mathrm{L}^{-1}\right)$, by titration; and TSS/TA ratio by the formula TSS/(TA $x$ 0.0075) (RIBÉREAU-GAYON et al., 1982).
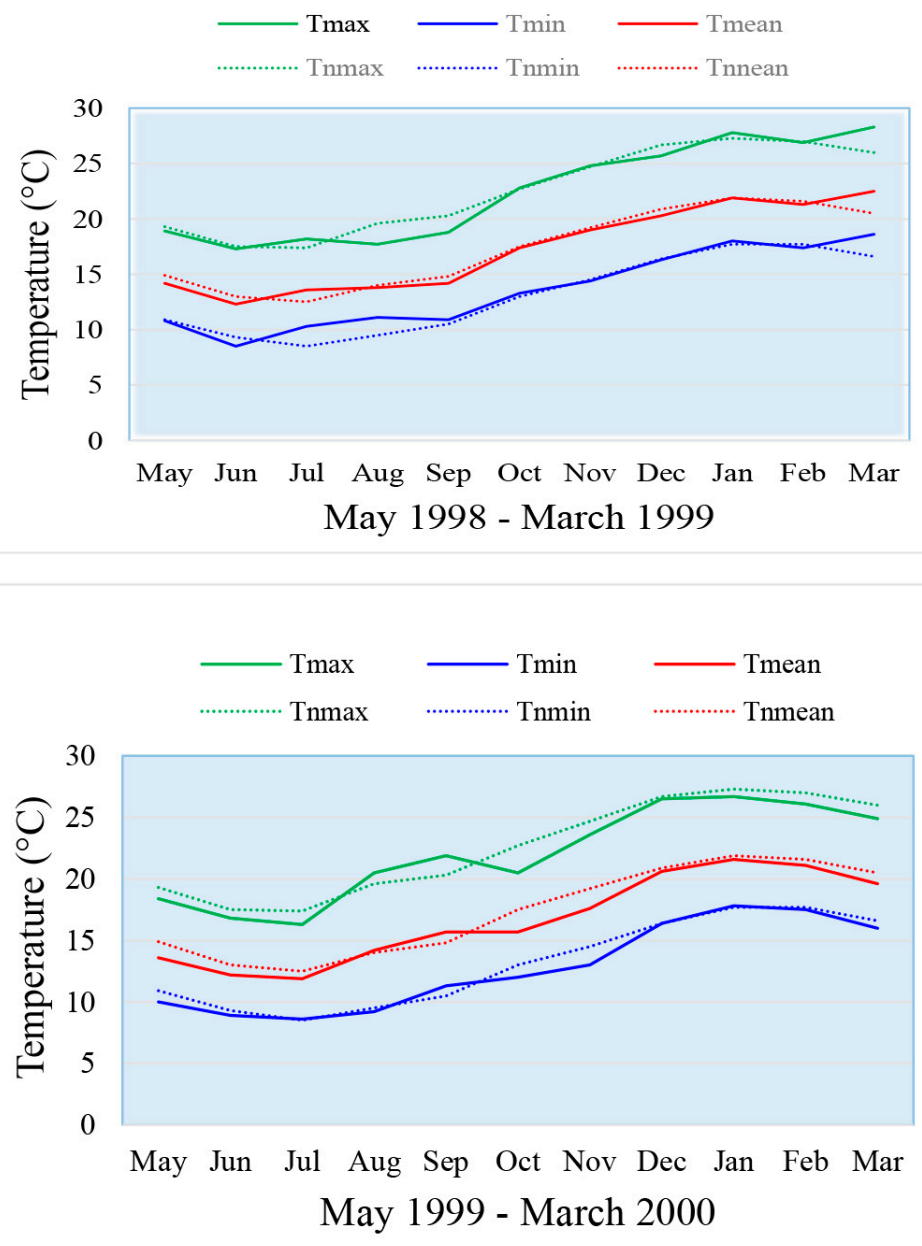

Figure 1. Maximum (Tmax), minimum (Tmin) and mean (Tmean) temperatures from May 1998 to March 1999 and from May 1999 to March 2000, and climatological normals (Tnmax, Tnmin and Tnmean) from 1981 to 2010 of Bento Gonçalves, Brazil.

The temperatures from May to budbreak dates were recorded in a thermograph of the Embrapa Uva e Vinho agroclimatological facility, which was near to the experimental vineyard. The chilling requirement for budbreak was the sum of temperatures $\leq 10^{\circ} \mathrm{C}$ from May to the budbreak date of each $\mathrm{CS} /$ rootstock combination.

The growing degree day (GDD) was the daily mean temperature minus the base temperature. The GDD for the thermal needs (heat summation) from budbrake to fruit maturity of each CS/rootstock were calculated according to the formula:

$$
\text { GDD }=\sum(\text { Tmean }- \text { Tbase })
$$

where $\mathrm{GDD}=$ growing degree days, Tmean $=$ mean daily temperature and Tbase $=$ base temperature $\left(10^{\circ} \mathrm{C}\right)$.
Temperatures were assessed at 9:00 a.m., 3:00 p.m. and 9:00 p.m. (the 3:00 a.m. temperature was not assessed because at that time there was no automatic climatic facility). In this way, the formula for calculating the mean daily temperature was:

$$
\text { Tmean }=[\text { T9a.m. }+(2 * \text { T9p.m. })+\text { Tmax }+ \text { Tmin })] / 5 \text {, }
$$

where Tmean $=$ mean daily temperature, T9a.m.= temperature at 9:00 a.m., T9p.m. $=$ temperature at 9:00 p.m., Tmax $=$ maximum daily temperature, $T \min =$ minimum daily temperature.

The correlation between the percentage of burst buds and the chill units were determined for each CS/rootstock. The number of days and the GDD for each phenology interval of the $15 \mathrm{CS} /$ rootstock were 
determined, that is budbreak-flowering, floweringveraison, veraison-maturity and budbreak-maturity. Curves of heat accumulation of the budbreak-maturity interval were drawn for two years.

\section{Results and Discussion}

The phenology stages of Cabernet Sauvignon grapevine grafted on different rootstocks, the chilling requirement to break the vine dormancy and the accumulation of heat required to ripen the grapes are shown in the next four sections.
Dates of phenology stages, number of days between each stage and from vine budbreak to grape maturity

The dates of the Cabernet Sauvignon vine budbreak and flowering, and veraison and maturity of the grape are shown in Table 1 (1998/1999) and Table 2 (1999/2000).

Table 1. Dates of phenology stages (1998/1999) of Cabernet Sauvignon grapevine grafter on different rootstocks.

\begin{tabular}{|c|c|c|c|c|}
\hline \multirow{2}{*}{ Rootstock } & Budbreak & Flowering & Veraison & Maturity \\
\hline & \multicolumn{4}{|c|}{ Month/Day } \\
\hline \multirow{2}{*}{ Isabel Dogridge } & $09 / 23$ & $11 / 10$ & $01 / 13$ & $03 / 01$ \\
\hline & $10 / 01$ & $11 / 11$ & $01 / 13$ & $02 / 28$ \\
\hline Fercal & $09 / 25$ & $11 / 08$ & $01 / 13$ & $02 / 26$ \\
\hline Gravesac & $09 / 22$ & $11 / 06$ & $01 / 11$ & $02 / 26$ \\
\hline $110 \mathrm{R}$ & $09 / 21$ & $11 / 06$ & $01 / 09$ & $03 / 04$ \\
\hline $99 \mathrm{R}$ & $09 / 24$ & $11 / 07$ & $01 / 11$ & $03 / 03$ \\
\hline $1103 \mathrm{P}$ & $09 / 21$ & $11 / 08$ & $01 / 12$ & $03 / 04$ \\
\hline Solferino & $09 / 25$ & $11 / 07$ & $01 / 11$ & $03 / 06$ \\
\hline SO4 & $09 / 22$ & $11 / 07$ & $01 / 11$ & $03 / 03$ \\
\hline $161-49 \mathrm{C}$ & $09 / 20$ & $11 / 08$ & $01 / 10$ & $03 / 02$ \\
\hline $5 \mathrm{BB} \mathrm{K}$ & $09 / 24$ & $11 / 08$ & $01 / 15$ & $03 / 06$ \\
\hline 420A Mgt & $09 / 24$ & $11 / 06$ & $01 / 11$ & $03 / 02$ \\
\hline $3309 \mathrm{C}$ & $09 / 19$ & $11 / 07$ & $01 / 09$ & $02 / 25$ \\
\hline 101-14 Mgt & $09 / 21$ & $11 / 07$ & $01 / 07$ & $02 / 25$ \\
\hline Rupestris du Lot & $09 / 23$ & $11 / 07$ & $01 / 12$ & $02 / 28$ \\
\hline Mean & $09 / 23$ & $11 / 08$ & $01 / 11$ & $03 / 01$ \\
\hline Standard deviation & 2.7 & 1.4 & 2.0 & 3.0 \\
\hline
\end{tabular}

Table 2. Dates of phenology stages (1999/2000) of Cabernet Sauvignon grapevine grafted on different rootstocks.

\begin{tabular}{|c|c|c|c|c|}
\hline \multirow{2}{*}{ Rootstock } & Budbreak & Flowering & Veraison & Maturity \\
\hline & \multicolumn{4}{|c|}{ Month/Day } \\
\hline Isabel & $09 / 24$ & $11 / 12$ & $01 / 14$ & $03 / 18$ \\
\hline Dogridge & $09 / 30$ & $11 / 15$ & $01 / 15$ & $03 / 13$ \\
\hline Fercal & $09 / 22$ & $11 / 05$ & $01 / 11$ & $03 / 13$ \\
\hline Gravesac & $09 / 21$ & $11 / 05$ & $01 / 10$ & $03 / 12$ \\
\hline $110 \mathrm{R}$ & $09 / 23$ & $11 / 10$ & $01 / 11$ & $03 / 13$ \\
\hline $99 \mathrm{R}$ & $09 / 22$ & $11 / 12$ & $01 / 14$ & $03 / 12$ \\
\hline $1103 \mathrm{P}$ & $09 / 22$ & $11 / 07$ & $01 / 11$ & $03 / 12$ \\
\hline Solferino & $09 / 23$ & $11 / 12$ & $01 / 14$ & $03 / 12$ \\
\hline $\mathrm{SO} 4$ & $09 / 24$ & $11 / 10$ & $01 / 12$ & $03 / 10$ \\
\hline $161-49 \mathrm{C}$ & $09 / 17$ & $11 / 07$ & $01 / 10$ & $03 / 12$ \\
\hline $5 \mathrm{BB} \mathrm{K}$ & $09 / 24$ & $11 / 08$ & $01 / 13$ & $03 / 13$ \\
\hline 420A Mgt & $09 / 19$ & $11 / 10$ & 01/09 & $03 / 15$ \\
\hline 3309 C & $09 / 18$ & $11 / 04$ & $01 / 11$ & $03 / 14$ \\
\hline 101-14 Mgt & $09 / 19$ & $11 / 12$ & $01 / 12$ & $03 / 11$ \\
\hline Rupestris du Lot & $09 / 19$ & $11 / 05$ & $01 / 10$ & $03 / 12$ \\
\hline Mean & $09 / 22$ & $11 / 09$ & $01 / 12$ & $03 / 13$ \\
\hline Standard deviation & 3.4 & 3.2 & 1.8 & 1.9 \\
\hline
\end{tabular}


The dates of each CS/rootstock stage varied according to the years. The average of two years, for all CS/rootstocks, showed that the earliest to sprout were CS/3309 C, CS/101-14 Mgt (both $V$. riparia $\times$ V. rupestris) and CS/161-49 C (V. berlandieri $\mathrm{x} V$. riparia) and the latest, CS/Dogridge (V. champini). The differences between the first and last budbreak dates were 12 days (1998) and 13 days (1999). The mean dates of all CS/ rootstocks budbreak were September $23^{\text {th }} \pm 2.7$ (1998) and September $22^{\text {th }} \pm 3.4$ (1999).

Most CS/rootstocks bloomed with a difference of a few days, being five days in 1998 and 11 days in 1999. The CS/3309 C, CS/Gravesac, CS/Rupestris du Lot, CS/ Fercal, CS/1103 P and CS/161-49 C started to bloom earlier and CS/Dogridge, later. The mean flowering dates of all CS/rootstocks were on November $8^{\text {th }} \pm 1.4$ (1998) and November $9^{\text {th }} \pm 3.2$ (1999).

A group of seven $\mathrm{CS} /$ rootstocks began to ripen earlier, such as CS/101-14 Mgt, CS/110 R, CS/161-49 C, CS/3309 C, CS/420A Mgt, CS/Gravesac and CS/ Rupesrtris du Lot and later in CS/Dogridge, CS/Isabel and CS/Solferino. The mean veraison dates of all CS/ rootstocks were on January $11^{\text {th }} \pm 2.0$ (1999) and January $12^{\text {th }} \pm 1.8(2000)$.

Grape maturity was earlier in CS/101-14 Mgt and CS/Rupestris du Lot followed by CS/Fercal, CS/Gravesac and $\mathrm{CS} / 3309 \mathrm{C}$, and later in CS/Isabel, CS/5BB K, CS/ SO4, CS/420A Mgt, CS/110 R and CS/1103 P. The mean dates of grape maturity of all CS/rootstocks were March $1^{\text {st }} \pm 3.0$ (1999) and March $13^{\text {th }} \pm 1.9$ (2000).

The number of days between each phenology stage is shown in Figure $2(1998 / 1999)$ and Figure 3 (1999/2000), which varied according to the CS/rootstock and year. For the two years, the mean intervals were $19.9 \pm 3.0$ (pruning-budbreak), $46.8 \pm 3.0$ (budbreakflowering), $64.3 \pm 2.1$ (flowering-veraison), 54.6 \pm 6.1 (veraison-maturity) and 165.7 \pm 7.4 (budbreak-maturity).

The interval pruning-budbreak was almost the same in 1998 (20.0-day average) and 1999 (19.8-day average) (Figures 2 and 3), which reflects the pruning performed on September $3^{\text {rd }}$ and September $2^{\text {nd }}$, respectively, and the climatic conditions. The date of pruning of the vine's can advance or delay budbreak. Pruning was performed during the vine rest period when it just started to bleed. Some CS/rootstocks sprouted earlier and others later. An early sprouting should be avoided in frost-risk regions due to the likely plant and vineyard damages. In this case, the Dogridge rootstock might be suggested, despite its higher chilling requirement, relatively low percentage of burst buds and relatively low yield.
Research has already been done on the effect of the rootstock on dates and length of the grapevine phenology stages in other conditions, such as different soils, climates, cultural practices and genetic materials (SATO et al., 2008; TECCHIO et al., 2011, 2013; LOUREIRO et al., 2016). Other aspects of phenology were also studied as well as the effect of the pruning time (MURAKAMI et al., 2002; BRIGHENTI et al., 2015), maturity and harvest of the grapes out of season (SATO et al., 2008) and at two grape harvests per year (ANZANELLO et al., 2012).

The dates of the phenology stages and the intervals between the stages were studied on $V$. labrusca L. and $V$. vinifera L. varieties (MANDELLI et al., 2003; ROBERTO et al., 2004; BRIGHENTI et al., 2013; CARVALHO, 2016; NUNES et al., 2016; CAMPOS et al., 2017). In an extensive study, from 1984 to 1994, working with eight $V$. vinifera $\mathrm{L}$. and four $V$. labrusca $\mathrm{L}$. varieties, similar results were found for Cabernet Sauvignon (MANDELLI, 2002).

The pruning-budbreak interval was $20.0 \pm 2.9$ days in 1998, being CS/Dogridge the highest (28 days) and CS/3309 C (16 days), the lowest (Figure 2). In 1999, these data were 19.8 $\pm 3.2,28$ days (CS/Dogridge) and 15 days (CS/161-49 C), respectively (Figure 3 ). The twoyear mean was $19.9 \pm 2.9$ days, where $\mathrm{CS} / 161-49 \mathrm{C}$ and CS/3309 C (both with 16 days) and CS/101-14 Mgt (17.5 days) sprouted earlier and CS/Dogridge (28 days), later. Therefore, there was a difference of 12 days in 1998 and 13 days in 1999 between data extremes in each year, but the mean of the $15 \mathrm{CS} /$ rootstocks were similar in both years. Considering two years, the CS/Dogridge budbreak was 9 days later than the average of the other CS/rootstocks. 


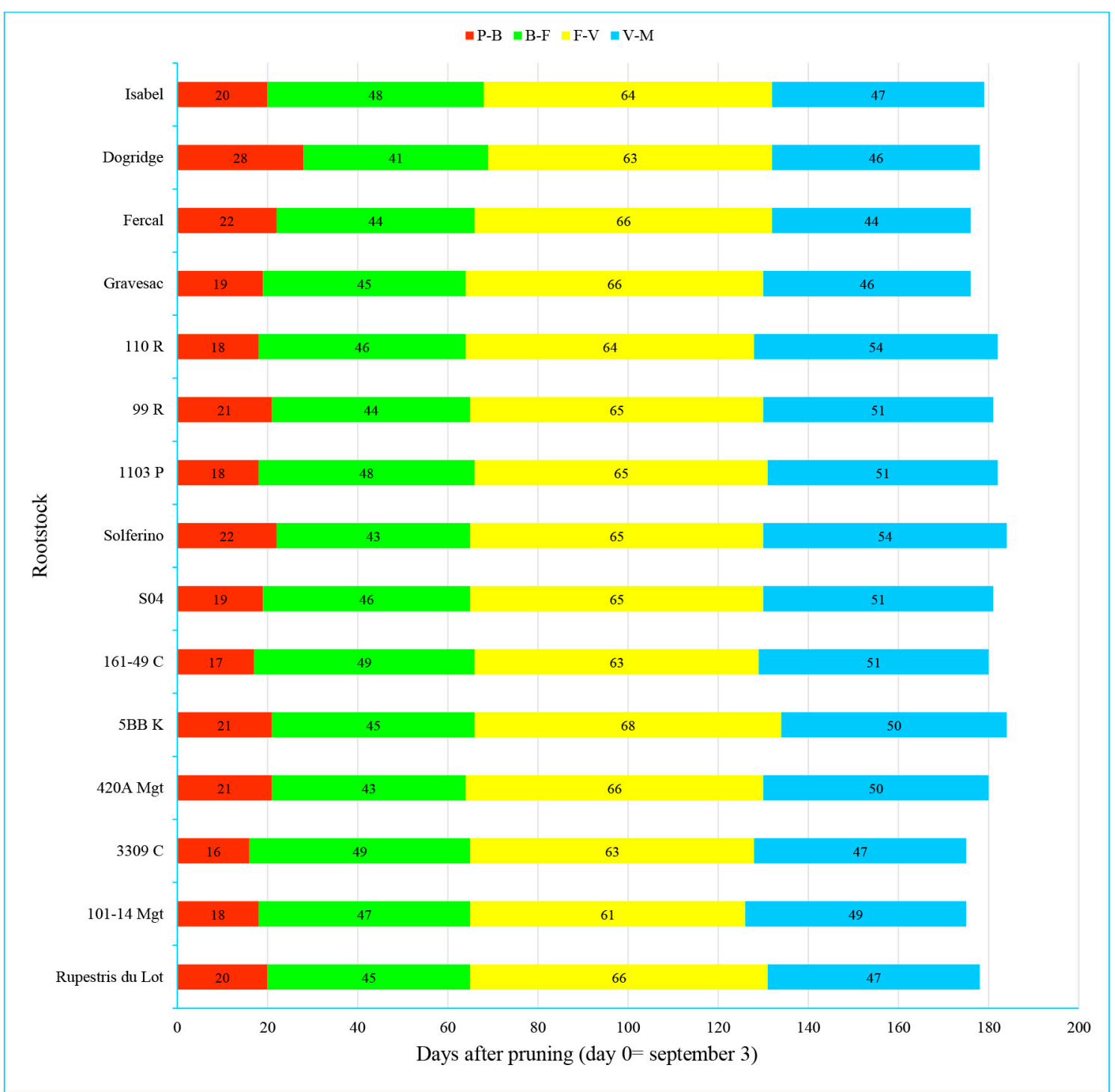

Figure 2. Intervals, in days, between the phenology stages of Cabernet Sauvignon grapevine according to the rootstock. Legend: $\mathrm{P}-\mathrm{B}=$ pruning-budbreak, $\mathrm{B}-\mathrm{F}=$ budbreak-flowering, $\mathrm{F}-\mathrm{V}=$ flowering-veraison, $\mathrm{V}-\mathrm{M}=$ veraison-maturity. Pruning was performed on September $3^{\text {rd }}$, 1998. Vine cycle: 1998/1999. 


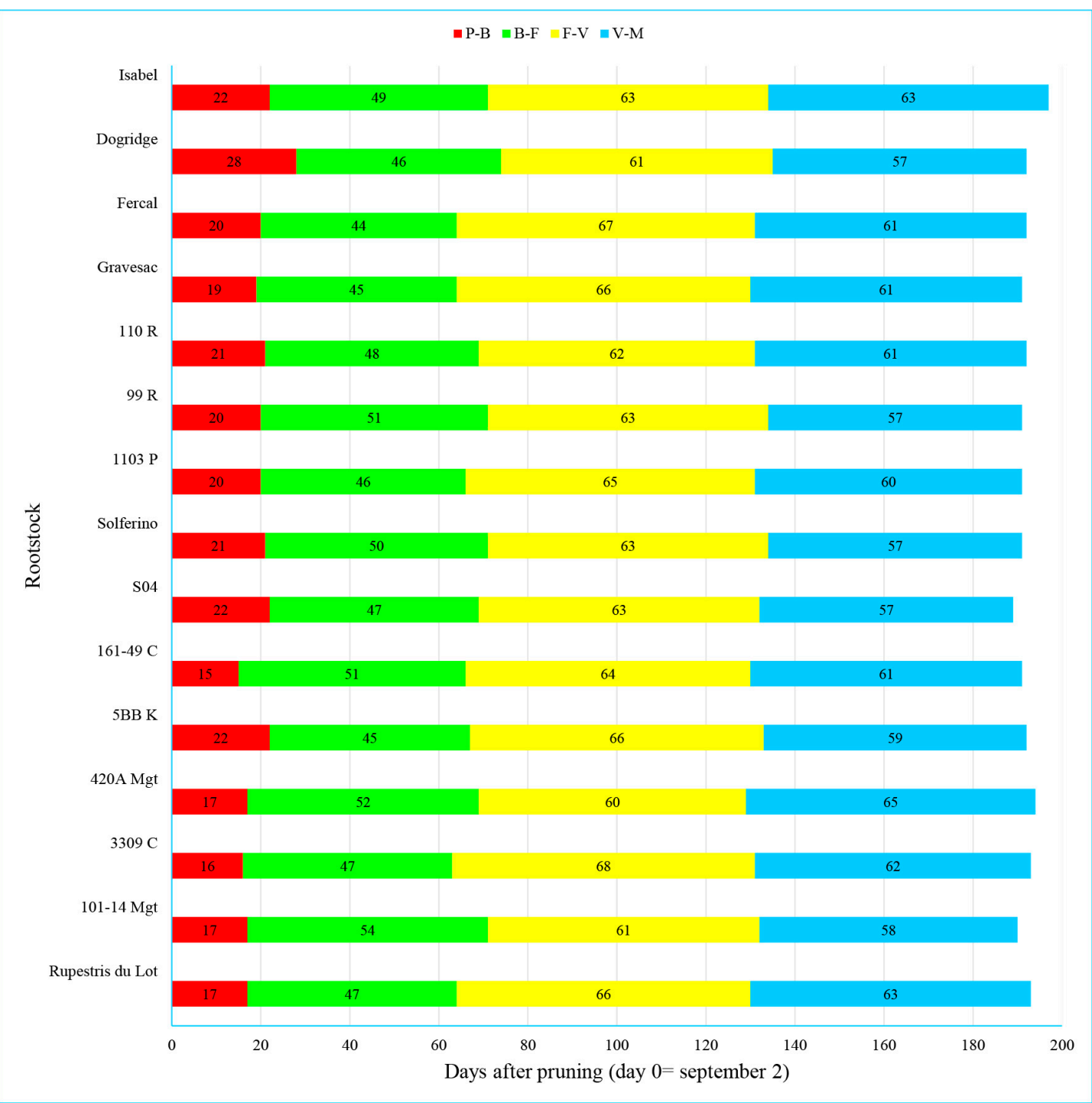

Figure 3. Intervals, in days, between the phenology stages of Cabernet Sauvignon grapevine according to the rootstock. Legend: $\mathrm{P}-\mathrm{B}=$ pruning-budbreak, $\mathrm{B}-\mathrm{F}=$ budbreak-flowering, $\mathrm{F}-\mathrm{V}=$ flowering-veraison, $\mathrm{V}-\mathrm{M}=$ veraison-maturity. Pruning was performed on September 2 ${ }^{\text {nd }}$, 1999. Vine cycle: 1999/2000.

\section{Percentage of sprouted buds}

In 1998, the sprouted-buds mean of all $15 \mathrm{CS} /$ rootstocks was $67.9 \pm 7.2 \%$, ranging from $48.5 \%$ in $\mathrm{CS} /$ Dogridge to $77.1 \%$ in $\mathrm{CS} / 420 \mathrm{~A} \mathrm{Mgt}$ and $76.4 \%$ in CS/110 $\mathrm{R}$. The differences were 28.6 and 27.9 percentage points compared to CS/Dogridge, respectively (Table 3). In 1999 , the budbreak mean of all $15 \mathrm{CS} /$ rootstocks was $75.8 \pm 4.8 \%$, ranging from $63.1 \%$ in CS/Dogridge to $82.8 \%$ in $\mathrm{CS} / 110 \mathrm{R}$ and $82.3 \%$ in $\mathrm{CS} / 161-49 \mathrm{C}$. However, all CS/rootstocks showed higher percentages of burst buds in 1999. Therefore, there were differences of 19.7 and 19.2 percentage points, respectively, compared to CS/ Dogridge. The two-year mean was $71.9 \pm 7.1 \%$ and the budbreak mean was 7.9 percentage points higher in 1999 than in 1998.
The budbreak percentage ranking of each CS/ rootstock varied according to the year. Taking the twocycle mean data, the highest values were in CS/110 R (79.6\%) and in CS/420A Mgt (78.3\%), and the lowest in CS/Dogridge (55.8\%), CS/3309 C (67.3\%), CS/Isabel (67.7\%) and CS Solferini (68.7\%).

\section{Chilling requirement for vine budbreak}

The chill hours recorded from May to October for the CS/rootstocks were 55.7\% higher in 1999 (983.8 h) than in 1998 (631.8 h), and from May to 50\% budbreak was $41.4 \%$ higher in $1999(870.6 \pm 6.5 \mathrm{~h})$ than 1998 $(615.9 \pm 8.5 \mathrm{~h})$ (Table 3). Thus, under normal conditions, the higher the number of chill hours, the higher the percentage of sprouted buds. It should also be pointed out that the chill hours in 1998 was the lowest in the 1988-2012 period (data from the Embrapa Uva e Vinho agroclimatological facility). 
Table 3. Chill hours from pruning to $50 \%$ budbreak and percentage of sprouted buds of Cabernet Sauvignon grapevine according to the rootstock.

\begin{tabular}{|c|c|c|c|c|}
\hline \multirow[b]{2}{*}{ Rootstock } & \multicolumn{2}{|l|}{1988} & \multicolumn{2}{|l|}{1999} \\
\hline & $\begin{array}{c}\text { Chill hours for } 50 \% \\
\text { budbreak }\end{array}$ & $\begin{array}{c}\text { Budbreak } \\
(\%)\end{array}$ & $\begin{array}{c}\text { Chill hours for } 50 \% \\
\text { budbreak }\end{array}$ & $\begin{array}{c}\text { Budbreak } \\
(\%)\end{array}$ \\
\hline Isabel & 615 & 62.5 & 876 & 72.8 \\
\hline Dogridge & 629 & 48.5 & 890 & 63.1 \\
\hline Fercal & 615 & 67.8 & 867 & 76.3 \\
\hline Gravesac & 615 & 71.4 & 867 & 79.7 \\
\hline $110 \mathrm{R}$ & 607 & 76.4 & 869 & 82.8 \\
\hline $99 \mathrm{R}$ & 615 & 69.3 & 867 & 77.5 \\
\hline $1103 \mathrm{P}$ & 607 & 66.9 & 867 & 76.8 \\
\hline Solferino & 615 & 62.7 & 869 & 74.6 \\
\hline $\mathrm{SO} 4$ & 615 & 75.3 & 876 & 76.0 \\
\hline $161-49 \mathrm{C}$ & 597 & 73.5 & 867 & 82.3 \\
\hline $5 B B \mathrm{~K}$ & 615 & 65.6 & 876 & 74.3 \\
\hline 420A Mgt & 615 & 77.1 & 867 & 79.6 \\
\hline $3309 \mathrm{C}$ & 597 & 63.0 & 867 & 71.5 \\
\hline 101-14 Mgt & 607 & 69.6 & 867 & 73.2 \\
\hline Rupestris du Lot & 615 & 68.9 & 867 & 76.8 \\
\hline Mean & 615.9 & 67.9 & 870.6 & 75.8 \\
\hline Standard deviation & 8.0 & 7.2 & 6.5 & 4.8 \\
\hline
\end{tabular}

Under temperate conditions, where most grapevines are grown, the buds enter endodormancy, which is the inhibition of growth by internal bud signals. It is a complex phenomenon controlled by a number of external and internal factors, leading to physiological changes. With increasing temperatures and sufficient soil moisture, as the cycle of the vine evolves, endodormancy ends and begins the so-called ecodormancy, which is defined as the inhibition of growth by temporary unfavorable environmental conditions (LANG et al., 1987). So unfavorable growing conditions simultaneously break endodormancy and impose ecodormancy (KELLER, 2010).

Grapevines undergo dormancy during their vegetative cycle, except in tropical regions where they remain green unless appropriate cultural practices, such as defoliation and application of budbreak promoters. After a continuous period of cold, the budbreak usually occurs earlier, faster and more uniformly (ANTCLIFF; MAY, 1961). In addition, longer periods of chilling and lower temperature accelerate budbreak rate, as warmer temperatures return (LAVEE; MAY, 1997; KELLER, 2010). Thus, a period of chilling during dormancy is desirable with minimum variation to obtain a uniform and high percentage of burst buds. This makes the pruning of the vine easier in the next winter and, mainly, leads to a more uniform grape ripening, which is important for the grape and wine quality.
The temperature for budbreak varies according to the species and varieties (POUGET, 1972). The species are classified as low $(<1,000)$ and high $(>1,000)$ chill hours. The grape varieties also have different chilling needs, where Cabernet Sauvignon required 1,250 chill hours to sprout (LONDO; JONHSON, 2014). In the present study, as average of the $15 \mathrm{CS} /$ rootstocks, in 1998 it took $615.9 \pm 8.0 \mathrm{~h}$ to reach $50 \%$ burst buds and $631.8 \mathrm{~h}$ for $67.9 \pm 7.2 \%$ burst buds; in 1999 these values were $870.6 \pm 6.5 \mathrm{~h}$ and $983.8 \mathrm{~h}$, respectively. Therefore, in 199815.9 additional hours of chilling were needed to reach the maximum percentage of sprouted buds

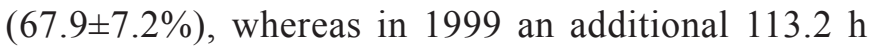
were required to reach $75.8 \pm 4.8 \%$. These results imply that under the climatic conditions of Serra Gaúcha the Cabernet Sauvignon vine needs higher chill hours, without intermittent warm periods, to sprout fast and uniformly.

The lack of water in the soil can also inhibit budbreak (HORVATH et al., 2003), because the moisture of the buds during dormancy is about $50 \%$ and when they sprout, 80\% (LAVEE; MAY, 1997). However, this was not the case for this experiment, where rainfall was $519.3 \mathrm{~mm}$ and $339.6 \mathrm{~mm}$ from June to August, 1998 and 1999 , respectively. 
The pruning time and the pruning system are other points to be considered. In cool climates, pruning vines shortly after grape harvest will not negatively affect vine phenology, but will extend the period for pruning the vine; late pruning, slightly retards budbreak, which could be desired for frost-risk regions (TROUGHT et al., 2011), while pruning earlier may advance sprouting. Also, spur pruned grapevines present, under the same conditions, a higher percentage of burst buds than those cane pruned.

\section{Heat requirement to ripen the grape}

The GDD between the stages of Cabernet Sauvignon grapevine are shown in Figure 4 (1998/1999) and Figure 5 (1999/2000). It varied according to the CS/ rootstock and the year. For all CS/rootstocks, the means of the GDD in 1998/1999 and 1999/2000 were (in ${ }^{\circ} \mathrm{C}$ ), respectively, $322.5 \pm 8.7$ and $279.2 \pm 15.0$ (budbreakflowering), $662.3 \pm 18.7$ and $641.8 \pm 15.6$ (floweringveraison), $590.3 \pm 40.8$ and $676.5 \pm 29.3$ (veraison-maturity) and $1573.4 \pm 43.0$ and $1599.4 \pm 25.5$ (budbreak-maturity). The GDD was almost of the same magnitude in both years, being only $1.65 \%$ higher in $1999 / 2000$ because the ripening period was longer and the average temperature was lower (Figure 6).

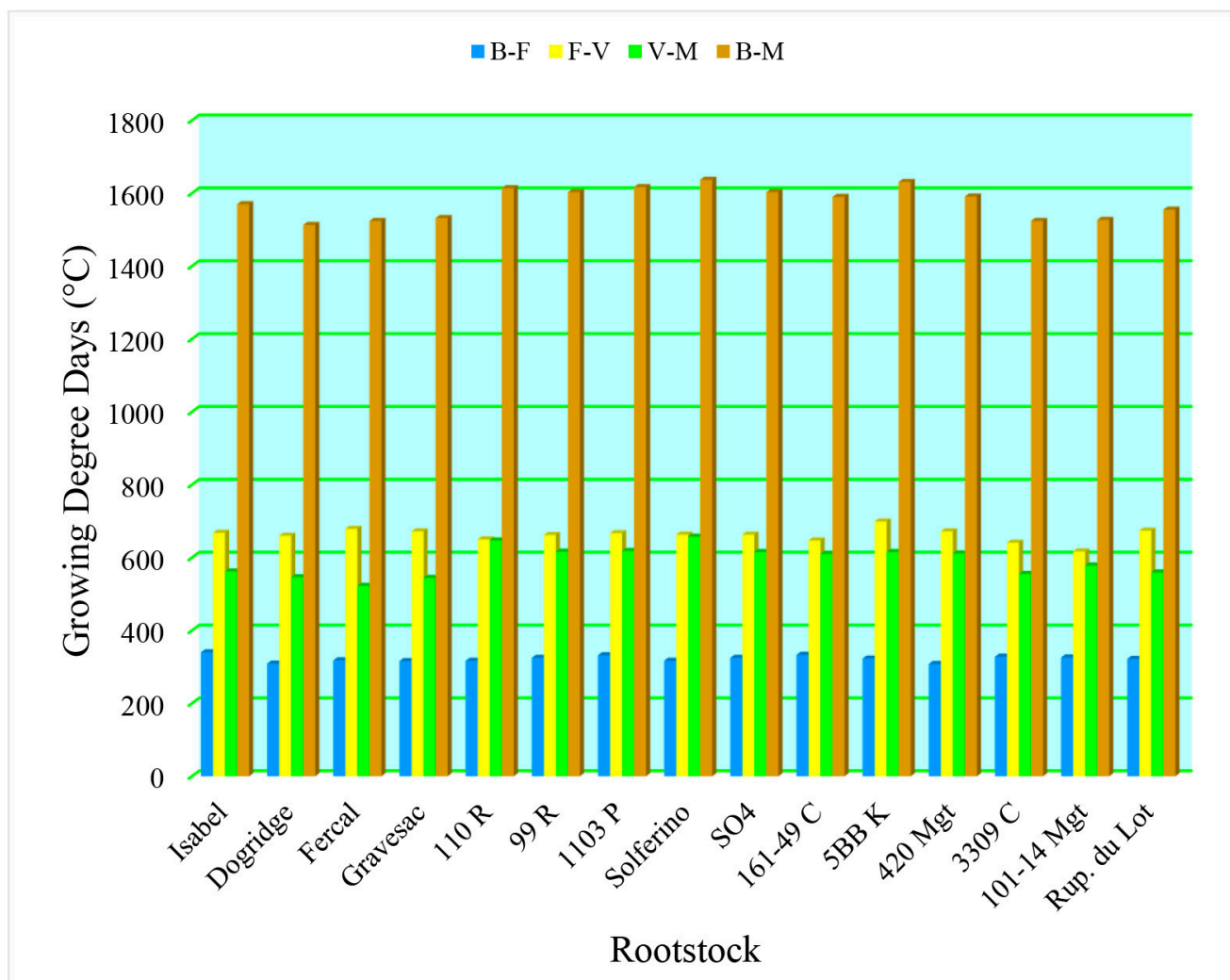

Figure 4. GDD $\left({ }^{\circ} \mathrm{C}\right)$ intervals of Cabernet Sauvignon grapevine according to the rootstock. Legend: B-F= budbreakflowering, F-V= flowering-veraison, V-M= veraison-maturity, B-M= budbreak-maturity. Vine cycle 1998/1999. 


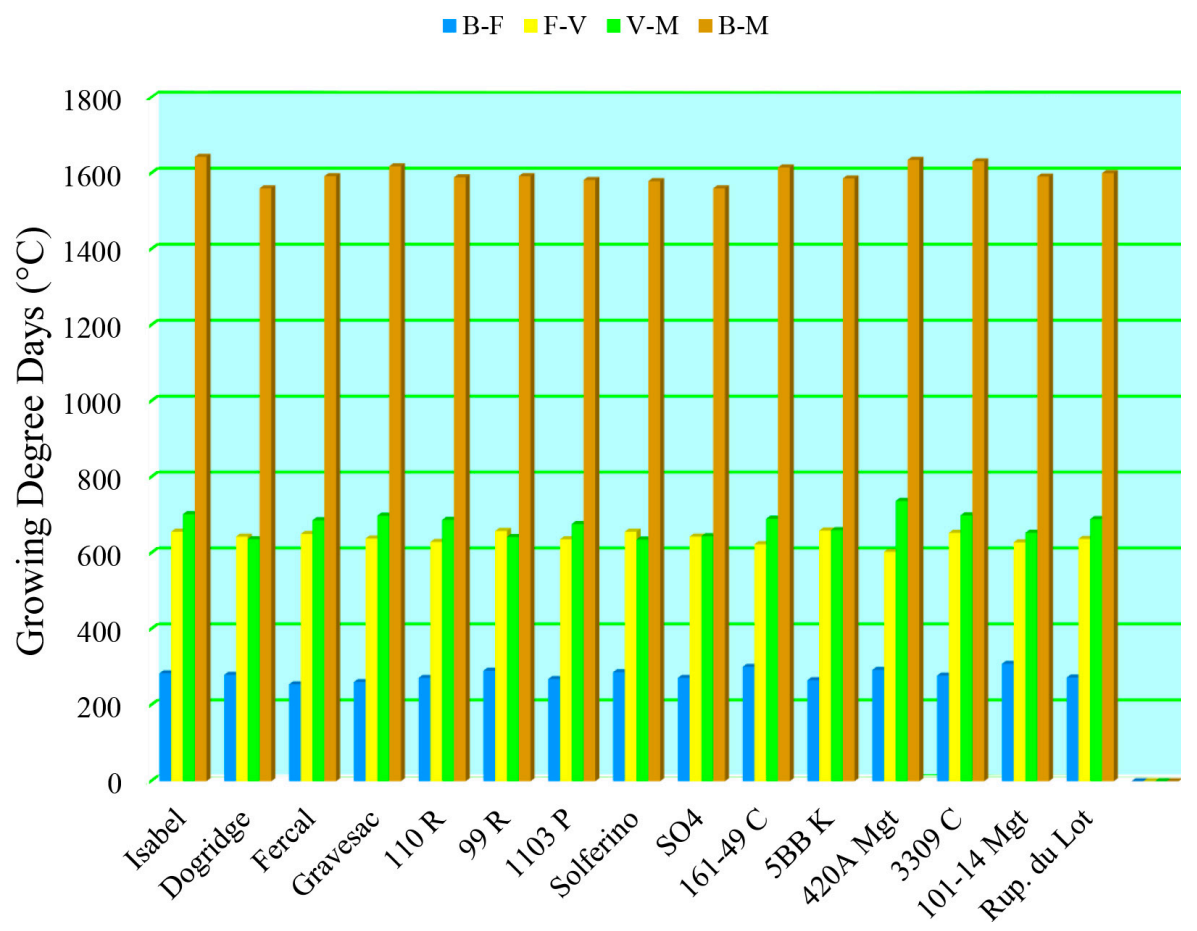

Figure 5. GDD $\left({ }^{\circ} \mathrm{C}\right)$ intervals of Cabernet Sauvignon grapevine according to the rootstock. Legend: B-F= budbreakflowering, F-V= flowering-veraison, V-M= veraison-maturity, B-M= budbreak-maturity. Vine cycle 1999/2000.

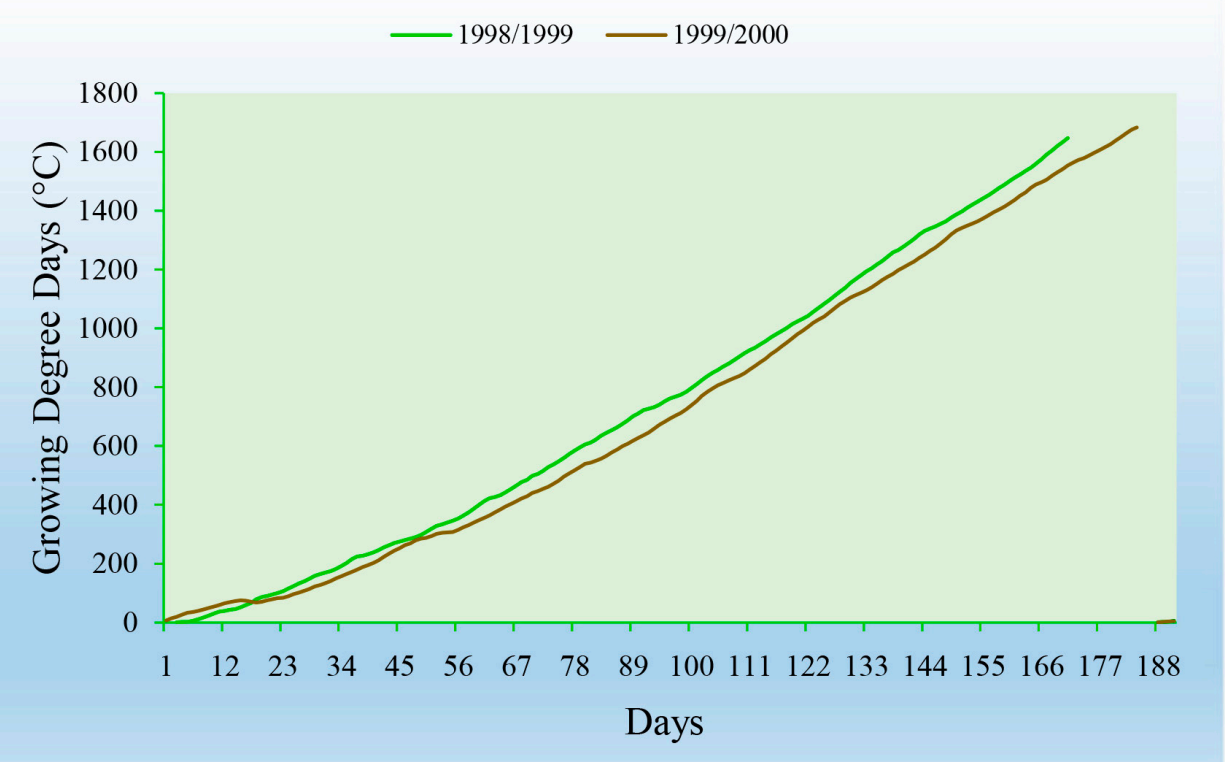

Figure 6. GDD evolution from September 19 $9^{\text {th }}, 1998$ to March 6 $6^{\text {th }}, 1999$ (green) and September $17^{\text {th }}, 1999$ to March $18^{\text {th }}, 2000$ (brown).

From February $15^{\text {th }}$ to March $15^{\text {th }}$, rainfall was $65.2 \mathrm{~mm}$ in 1999 and $129.5 \mathrm{~mm}$ in 2000 . As the climatic conditions are very important factors for grape ripening, the highest volume of rainfall in the last 15-20 days from maturity in 2000 caused differences in TSS in the juices. These differences were favorable to the 1998/1999 grapes compared to the 1999/2000, because their juices had, respectively, higher TSS (19.1 and $18.1^{\circ}$ Brix), lower TA (131 and 135 meq. $\left.\mathrm{L}^{-1}\right)$ and higher TSS/TA ratio (19.5 and 18.0).
Some trials were carried out around the world determining the GDD between the phenology stages of grapevines. A 10 year-average work on Cabernet Sauvignon in Serra Gaúcha showed that the GDD from budbreak to maturity was $1553.6^{\circ} \mathrm{C}$ (MANDELLI, 2002), very similar to the data of the present study. Nevertheless, in southern Brazilian regions the GDD of this variety grown in higher altitudes displayed the following values $\left({ }^{\circ} \mathrm{C}\right)$ : budbreak-flowering (387), flowering-veraison (521), veraison-maturity (522) and budbreak-maturity 
(1430) (BRIGHENTI et al., 2013) and in the subtropical conditions Cabernet Sauvignon required only $1007.4{ }^{\circ} \mathrm{C}$ from budbreak to maturity (ROBERTO et al., 2005).

Other studies on GDD were carried out in different places, grapevine varieties or cultural practices (ROBERTO et al., 2004; NEISS et al., 2010; ANZANELLO et al., 2012; TECCHIO et al., 2013; BRIGHENTI et al., 2015; NUNES et al., 2016; CARVALHO, 2016). There are differences between the results of these trials and those of the present study, which are mainly due to terroir, cultural practices and genetic material used in the experiments. In addition, the differences related to the phenology dates and the chilling and heat requirements found between $\mathrm{CS} /$ rootstocks might be due, directly or indirectly, to the genetic diversity of the rootstocks and their interrelationships with the scion and the environment.

Cabernet Sauvignon is a long cycle variety that needs warm, dry summer conditions. Therefore, it seems that the GDD of the Serra Gaúcha region should be higher than that of the two evaluated years. Indeed, clear days is an important factor for photosynthesis to produce sugar in the leaves and its accumulation in grapes and, at the same time, other biochemical reactions are processed. The air temperature increases the fruit temperature in the final days of grape ripening, which causes loss of water, concentrating its juice. Another point to be taken into consideration is that on a clear day it does not rain and the incidence of diseases is much lower, which is desirable for the quality of the grape.

\section{Conclusion}

The rootstock has an effect on the phenology stage dates and duration of Cabernet Sauvignon grapevines, as well as on the chilling requirements to break vine dormancy and on the heat requirements to ripen grapes. However, the values of each CS/rootstock varies according to the year. Chill hours for budbreak should be higher to ensure a desirable percentage of burst buds and, especially, a uniform sprouting. As Cabernet Sauvignon has a relatively long cycle, longer and clearer days are needed to ripen the grape.

\section{Acknowlegments}

The author would like to express his gratitude to the colleagues at Embrapa Uva e Vinho, especially Dr. Luiz Antenor Rizzon and to the people who contributed to the experiment by managing the vineyard and collecting the data. Many thanks also go to Mr. Dalton Zatt and Mr. Adriel Marconatto who organized the climate data, and the Inra-Centre Bordeaux-Aquitaine that kindly provided the rootstocks Fercal and Gravesac to the research.

\section{References}

ACOSTA, E.; CANZIANI, P.; CAVAGNARO, M. Regional climate variability impacts on the annual grape yield in Mendoza, Argentina. Journal of Applied Meteorology and Climatology, Boston, v.51, n.6, p.9931009, 2012.

ALLEBRANDT, R.; MARCON FILHO, J.L.; BEM, B.P. de; WÜRZ, D.A.; BRIGHENTI, A.F.; KRETZSCMAR, A.A.; RUFATO, L. Fenologia da variedade Merlot produzida sobre três porta-enxertos em elevadas altitudes de Santa Catarina. Revista Brasileira de Viticultura e Enologia, Bento Gonçalves, n.7, p.36-43, 2015.

ANTCLIFF, A.J.; MAY, P. Dormancy and bud burst in Sultana vines. Vitis, Siebeldingen, v.3, n.1, p.1-14, 1961.

ANZANELlO, R.; SOUZA, P.V.D. de; COELHO, P.F. Fenologia, exigência térmica e produtividade de videiras 'Niagara Branca', 'Niagara Rosada' e 'Concord' submetidas a duas safras por ciclo vegetativo. Revista Brasileira de Fruticultura, Jaboticabal, v.34, n.2, p.366376, 2012.

BENJAMIN, A.M. da S.; DANTAS, D.J.; DANTAS, D.J.; NUNES, G.H. da S.; POMMER, C.V.; BRESSANSMITH, R.; MENDONÇA, V. Development of 'Italia Melhorada' grapes on different rootstocks and under the semiarid conditions of the Rio Grande do Norte State, Brazil. Semina: Ciências Agrárias, Londrina, v.39, n.5, p.1867-1878, 2018.

BRIGHENTI, A.F.; BRIGHENTI, E.; BONIN, V.; RUFATO, L. Caracterização fenológica e exigência térmica de diferentes variedades de uvas viníferas em São Joaquim, Santa Catarina - Brasil. Ciência Rural, Santa Maria, v.43, n.7, p.1162-1167, 2013.

BRIGHENTI, A.F.; MALINOVSKI, L.I.; STEFANINI, M.; VIEIRA, H.J.; SILVA, A.L. da. Comparação entre as regiões vitícolas de São Joaquim - SC, Brasil e San Michele all'Adige, TN, Itália. Revista Brasileira de Fruticultura, Jaboticabal, v.37, n.2, p.281-288, 2015.

CABRÉ, M.F.; QUÉNOL, H.; NUÑEZ, M. Regional climate change scenarios applied to viticultural zoning in Mendoza, Argentia. International Journal of Biometeorology, Ottawa, v.60, n.9, p.1325-1340, 2016. 
CAMPOS, T.C.; MALINONSKI, L.I.; MATOS, D.P. de; FERRARI, L.; SILVA, A.L. da. Comportamento vitícola das variedades Chardonnay e Vermentino na Serra Catarinense. Revista Brasileira de Viticultura e Enologia, Bento Gonçalves, n.9, p.26-32, 2017.

CARVALHO, E. de. Fenologia, exigência térmica e produção de cultivares de videiras (Vitis spp.) em Lavras-MG. 2016. 63f. Tese (Doutorado em Produção Vegetal), Universidade Federal de Lavras, Lavras, 2016.

DUCHÊNE, E.; BUTTERLIN, G.; DUMAS, V.; MERDINOGLU, D. Towards the adaptation of grapevine varieties to climate change: QTLs and candidate genes for developmental stages. Theoretical and Applied Genetics, Berlin, v.124, n.4, p.623-635, 2012.

FRAGA, H.; SANTOS, J.A.; MOUTINHO-PEREIRA, J.; CARLOS, C.; SILVESTRE, S.; EIRAS-DIAS, J.; MOTA, T.; MALHEIRO, A.C. Statistical modelling of grapevine phenology in Portuguese wine regions: observed trends and climate change projections. The Journal of Agricultural Science, Cambridge, v.154, n.5, p. 795-811, 2016.

GATTI, M.; PIREZ, F.J.; CHIARI, G.; TOMBESI, S.; PALliOTTI, A.; MERLI, M.C.; PONI, S. Phenology, canopy aging and seasonal carbon balance as related to delayed winter pruning of Vitis vinifera L. cv. Sangiovese grapevines. Frontiers in Plant Science, New Haven, v.7, n. $659,2016$.

HALL, A.; MATHEWS, A.J.; HOLZAPEL, B.P. Potential effect of atmospheric warming on grapevine phenology and post-harvest heat accumulation across a range of climates. International Journal of Biometeorology, Ottawa, v.60, n.9, p.1405-1422, 2016.

HORVATH, D.P.; ANDERSON, J.V.; CHAO, W.S.; FOLEY, M.E. Knowing when to grow: signals regulating bud dormancy. Trends in Plant Science, Amsterdam, v.8, p.534-540, 2003.

INMET- Instituto Nacional de Meteorologia. Clima. Normais climatológicas do Brasil. Disponível em: http://www.inmet.gov.br/portal/index.php?r=clima/ normaisClimatologicas. Acesso em: 12 dez. 2018.

IPCC - Intercovernamental Panel on Climatic Changes. Climate change 2015: mitigation of climate change. Cambridge: Cambridge University, 2015. Disponível em: https://doi.org/10.1017/CBO9781107415416.
JONES, G.V.; DAVIS, R.E. Climate influences on grapevine phenology, grape composition, and wine production and quality for Bordeaux, France. American Journal of Enology and Viticulture, Davis, v.51, n.3, p.249-261, 2000.

KELLER, M. The science of grapevines: anatomy and physiology. Amsterdam: Elsevier, 2010.

LANG, G.A.; EARLY, J.D.; MARTIN, J.C.; DARNELL, R.L. Endo-, para- and eco-dormancy: physiological terminology and classification for dormancy research. HortScience, Alexandria, v.22, n.3, p.371-377, 1987.

LAVEE, S.; MAY, P. Dormancy of grape buds: facts and speculation. Australian Journal of Grape and Wine Research, Adelaide, v.3, n.1, p.31-46, 1997.

LONDO, J.P.; JOHNSON, L.M. Variation in the chilling requirement and budburst rate of wild Vitis species. Environmental and Experimental Botany, Oxford, v.106, p.138-147, 2014.

LORENZ, D.H.; EICHHORN, K.W.; BLEIHOLDER, H.; KLOSE, R.; MEIER, U.; WEBER, E. Phenological growth stages of the grapevine (Vitis vinifera spp. vinifera) - codes and descriptions according to the extended BBCH scale. Australian Journal of Grape and Wine Research, Adelaide, v.1, n.2, p.100-103, 1995.

LOUREIRO, M.D.; MORENO-SANZ, P.; GARCÍA, A.; FERNÁNDEZ, O.; FERNÁNDEZ, N.; SUÁREZ, $B$. Influence of rootstock on the performance of the Albarín Negro minority grapevine cultivar. Scientia Horticulturae, New York, v.201, p.145-152, 2016.

MANDELLI, F. Relações entre variáveis meteorológicas, fenologia e qualidade da uva na "Serra Gaucha". 2002. 196f. Tese (Doutorado em Agrometeorologia) - Faculdade de Agronomia, Universidade Federal do Rio Grande do Sul, Porto Alegre, 2002.

MANDELLI, F.; BERLATO, M.A.; TONIETTO, J.; BERGAMASCHI, H. Fenologia da videira na Serra Gaucha. Pesquisa Agropecuária Brasileira, Brasília, DF, v.9, n.1-2, p.129-144, 2003.

MATHIASON, M.; HE, D.; GRIMPLET, J.; VENKATESWARI, J.; GALBRAITH, J.W.; OR, E.; FENNELL, A. Transcript profiling in Vitis riparia during chilling requirement fulfillment reveals coordination of gene expression patterns with optimized budbreak. Functional \& Integrative Genomics, Berlin, v.9, n.1, p.81-96, 2009. 
MIELE, A. Efeito da cianamida hidrogenada na quebra de dormência das gemas, produtividade do vinhedo e composição química do mosto da uva Cabernet Sauvignon. Pesquisa Agropecuária Brasileira, Brasília, DF, v.26, n.3, p.315-324, 1991.

MIELE, A.; RIZZON, L.A. Rootstock-scion interaction: 1. Effect on the yield components of Cabernet Sauvignon grapevine. Revista Brasileira de Fruticultura, Jaboticabal, v.39, n.1, e-280, 2017.

MORIONDO, M.; JONES, G.V.; BOIS, B.; DIBARI, C.; FERRISE, R.; TROMBI, B.; BINDI, M. Projected shifts of wine regions in response to climate change. Climate Change, Berlin, v.119, n.3-4, p.825-839, 2013.

MURAKAMI, K.R.N.; CARVALHO, A.J.C. de; CEREJA, B.S.; BARROS, J.C. da S. M. de; MARINHO, C.S. Caracterização fenológica da videira cv. Itália (Vitis vinifera L.) sob diferentes épocas de poda na região norte do Estado do Rio de Janeiro. Revista Brasileira de Fruticultura, Jaboticabal, v.24, n.3, p.615-617, 2002.

NEISS, S.; SANTOS, S.C.; ASSIS, K.C. de; MARIANO, Z. de F. Caracterização fenológica e requerimento térmico para a videira Niagara Rosada em diferentes épocas de poda no sudoeste goiano. Revista Brasileira de Fruticultura, Jaboticabal, v.32, n.3, p.931-937, 2010.

NUNES, N.A.S.; LEITE, A.V.; CASTRO, C.C. Phenology, reproductive biology and growing degree days of the grapevine 'Isabel' (Vitis labrusca, Vitaceae) cultivated in northeastern Brazil. Brazilian Journal of Biology, São Carlos, v.76, n.4, p.975-982, 2016.

PETRIE, P.R.; BROKE, S.J.; MORAN, M.A.; SADRAS, V.O. Pruning after budburst to delay and spread grape maturity. Australian Journal of Grape and Wine Research, Adelaide, v.23, p.378-389, 2017.

POUGET, R. Considérations générales sur le rythme végétatif de la dormance des bourgeons de la vigne. Vitis, Siebeldingen, v.11, n.3, p.198-217, 1972.

RIBÉREAU-GAYON, J.; PEYNAUD, E.; SUDRAUD, P.; RIBÉREAU-GAYON, P. Traité d'œnologie: sciences et techniques du vin: analyse et contrôle des vins. 2.ed. Paris: Dunod, 1982.

ROBERTO, S.R.; SATO, A.J.; BRENNER, E.A.; JUBILEU, B. da S.; SANTOS, C.E. dos; GENTA, W. Caracterização fenológica e exigência térmica (graus-dia) para a uva 'Cabernet Sauvignon' em zona tropical. Acta Scientiarum. Agronomy, Maringá, v.27, n.1, p.183-187, 2005.
ROBERTO, S.R.; SATO, A.J.; BRENNER, E.A.; SANTOS, C.E. dos; GENTA, W. Fenologia e soma térmica (graus-dia) para a videira 'Isabel' (Vitis labrusca) cultivada no noroeste do Paraná. Semina: Ciêcias Agrárias, Londrina, v.25, n.4, p.273-280, 2004.

RUML, M.; KORAC, N.; VUJADINOVIC, M.; VUKOVIC, A.; IVANISEVIC, D. Response of grapevine phenology to recent temperature change and variability in the wine-producing area of Sremski Karlovci, Serbia. Journal of Agricultural Science, Cambridge, v.154, n.2, p.186-206, 2016.

SATO,A.J.; SILVA, B.J.; SANTOS, E. dos; BERTOLUCCI, R.; SANTOS, R. dos; CARIELO, M.; GUIRAUD, M.C.; FONSECA, I.C. de B.; ROBERTO, S.R. Fenologia e demanda térmica das videiras 'Isabel' e 'Rubea' sobre diferentes porta-enxertos na Região Norte do Paraná. Ciências Agrárias, Londrina, v.29, n.2, p.283-292, 2008.

SCHIEDECK, G.; MIELE, A.; BARRADAS, C.I.N.; MANDELLI, F. Fenologia da videira Niágara Rosada cultivada em estufa e a céu aberto. Revista Brasileira de Agrometeorologia, Santa Maria, v.5, n.2, p.199-206, 1997.

TECCHIO, M.A.; MOURA, M.F.; PAIOLI-PIRES, E.J.; TERRA, M.M. Efeito do porta-enxerto e da época de poda na duração das fases fenológicas e no acúmulo de grausdia pela videira 'Niagara Rosada'. Revista Brasileira de Fruticultura, Jaboticabal, v.35, n.4, p.1073-1080, 2013.

TECCHIO, M.A.; TERRA, M.M.; MOURA, M.F.; PAIOLI-PIRES, E.J. Fenologia e acúmulo de graus-dia da videira 'Niagara Rosada' cultivada ao noroeste do Estado de São Paulo. Revista Brasileira de Fruticultura, Jaboticabal, v.33, p.248-254, 2011. Número especial.

TROUGHT, M.C.T.; BENNETT, J.S.; BOLDINGH, H.L. Influence of retained cane number and pruning time on grapevine yield components, fruit composition and vine phenology of Sauvignon Blanc vines. Australian Journal of Grape and Wine Research, Adelaide, v.17, p.258-262, 2011.

URHAUSEN, S.; BRIENEN, S.; KAPALA, A.; SIMMER, C. Climatic conditions and their impact on viticulture in the Upper Moselle region. Climatic Change, Berlin, v.109, n.3-4, p.349-373, 2011. 
VERDUGO-VÁSQUEZ, N.; ACEVEDO-OPAZO, C.; VALDÉS-GÓMES, H.; ARAYA-ALMAN, M.; INGRAM, B.; GARCÍA DE CORTÁZAR-ATAURI, I.; TISSEYRE, B. Spatial variability of phenology in two irrigated grapevine cultivar growing under semi-arid conditions. Precision Agriculture, Boston, v.17, n.2, p.218-245, 2016.

VINK, N.; DELOIRE, A.; BONNARDOT, V.; EWERT, J. Climate change and the future of South Africa's wine industry. International Journal of Climate Change Strategies and Management, Bingley, v.4, n.4, p.420441, 2012.

WINKLER, A.J.; COOK, J.A.; KLIEWER, W.M.; LIDER, L.A. General viticulture. Berkeley: University of California, 1974.
ZAPATA, D.; SALAZAR, M.; CHAVES, B.; KELLER, M.; HOOGENBOOM, G. Estimation of the base temperature and growth stage duration in terms of thermal time for four grapevine cultivars. International Journal of Biometeorology, Ottawa, v.59, n.12, p.1771-1781, 2015 .

ZUFFEREY, V.; MURISIER, F.; VIVIN, P.; BELCHER, S.; LORENZINI, F.; SPRING, J.L.; VIRET, O. Carbohydrate reserves in grapevine (Vitis vinifera L. 'Chasselas'): the influence of the leaf to fruit ratio. Vitis, Siebeldingen, v.51, n.3, 103-110, 2012. 